\title{
Design Change Dynamics in Building Project: From Literature Review to A Conceptual Framework Formulation
}

\author{
Jeffrey Yap Boon Hui ${ }^{1}$, Hamzah Abdul-Rahman ${ }^{2}$ and Wang Chen ${ }^{3}$ \\ ${ }^{123}$ Faculty of Science, Technology, Engineering and Mathematics, International University of Malaya- \\ Wales, 50480 Kuala Lumpur, Malaysia \\ ${ }^{1}$ Lee Kong Chien Faculty of Engineering and Science, Universiti Tunku Abdul Rahman, Sungai Long \\ Campus, 43000 Kajang, Malaysia \\ ${ }^{1}$ bhyap@utar.edu.my
}

\begin{abstract}
Building construction projects worldwide routinely fail to meet their schedule and cost objectives. This paper focuses on design changes as the principal contributing factor to delay and cost overruns. Substandard project coordination and futile communication management are sustained problems with the construction industry, particularly as to the management of design changes. To rectify the captioned issues, this study is aimed at exploring the underlying causes of design changes, the resulting rework that is damaging to project performance, communication management process and collaboration in a project-based setting through the review of the literature. Qualitative analysis technique using content analysis method was employed to synthesise the literature and establishing relationships based on the key themes identified. A conceptual model for design change management was then formulated to be the notable outcome of this study. The framework describes the importance of applying effective communication process and informed management decision in dealing with design changes. It provides a coherent and holistic view to understand the dynamics of design changes in a building construction project. It aims to address the current methodological gap in construction management research that lacks demonstrable causality. The findings contribute useful starting point for future overrun causation and mitigation studies.
\end{abstract}

Keywords: design changes; delay; cost overrun; building construction; causality

\section{INTRODUCTION}

The construction industry worldwide is beleaguered with delay and cost overruns and Malaysia is no exception. This pandemic retard the national socioeconomic development and damaging to the building subsector which makes up over 60\% of total project value in 2015 (Construction Industry Development Board (CIDB), 2016). Notwithstanding the adverse implications of overruns, the phenomenon is a common occurrence. Over the years, extensive research has been steered on investigating the numerous possible causes of delay and cost overruns. Despite the continued research efforts, the magnitude of overruns in building projects has not improved, signifying that notable learning has not been transpired in alleviating 
the damaging consequences. Alarmingly, more than half of Malaysian project (55\%) experienced cost overruns (Shehu et al, 2014). Memon et al. (2011) completed a survey on 30 large construction projects in Malaysia which reported that almost 57\% of the projects suffered from 1-100 days of delay. Ahiaga-Dagbui et al. (2015) point out the methodological gap in the approaches used by most of the overruns studies. They assert the lack of systems or holistic conceptualization and without demonstrable causality lead to flawed simplification of the overruns problem and rather counterproductive. System dynamics or causal loop mapping is suggested as an alternative approach to investigate delay and cost overrun problem.

Delays and cost overruns in building projects are often associated with design changes. Olawale and Sun (2010) advocate the need to investigate the inhibiting factors to the successful implementation of project control processes. They carried out an industry-wide survey on 250 construction organisations in the UK to establish the prime factor that jeopardises project schedule and financial plans are design changes. Akin to other studies on the causes of delay and cost overruns (e.g. Assaf \& Al-Hejji, 2006; Kaming et al, 1997), design changes is acknowledged as a crucial problem. One of the many cases of overruns due to design changes in Malaysia is the construction of the new low-cost carrier terminal or commonly known as KLIA2. The project was severely delayed with huge cost overruns of over $200 \%$. The identified root cause is the enhancement of the design concept from budget to hybrid airport (Ng, 2015). Abdul-Rahman et al. (2006) reveal that practitioners in Malaysian construction industry acknowledge design changes as a critical problem need to be addressed. However, not all design changes are detrimental. In fact, some proactive changes may be beneficial to the whole-life value of the building (Charles, Wanigarathna, \& Sherratt, 2015) but this area is still currently under-researched. More often than not design changes are due to poor communication and lack of coordination among the project team (Love \& Sing, 2013).

Building construction is a project-based practice and design is an iterative process where deviations are unavoidable (Mohamad, Nekooie, \& Al-Harthy, 2012). Rework is a harmful consequence resulting from design changes (Abdul-Rahman, Wang, \& Yap, 2015). Despite previous scholars have acknowledged the adverse effects of rework to project performance, relatively few scholars have suggested rework mitigation through effective design management. For instance, Love et al. (1999) explored the rework causes in construction but stop short on suggesting the remedial measures. Williams et al. (1995) examined the inferences of design changes and interruptions on project costs but failed to recommend rework mitigation processes. These two domains are predominantly researched separately. Clearly, there seems to be a lack of studies associating design changes and rework studies in looking at delay and cost overruns research. This paper seeks to contribute by integrating design changes and rework in exploring design change management to enhance project delivery outcomes.

As building construction projects worldwide share some key characteristics (Olawale \& Sun, 2010), it is imperative to extend the research on managing design changes to include rework mitigation and effective communication. Therefore, the objective of this paper to derive a conceptual model to mitigate design changes through communication management in building construction projects for better delivery of project time and cost outcomes. This study is moving from the traditional net-effect correlational analysis to a search for causal relationships through system thinking to mend the pertinent problems of overruns. 
The premise of this paper is articulated around these propositions: (1) design changes have a significant relationship on rework; (2) rework have a significant and negative relationship on project time and cost performance; (3) project communication management have a significant and positive relationship on rework; and (4) effective communication have a significant and positive relationship on management decision-making (expert judgement).

\section{MANAGING DESIGN CHANGES}

In building construction projects, design changes refer to design deviances with regards to the design requirements of the project (Burati, Farrington, \& Ledbetter, 1992). These changes make up of any addons, exclusions or modifications were done to the original contract after award (Akinsola et al., 1997) which make construction projects dynamic and unstable (Park \& Peña-Mora, 2003), leading to variations in the project duration and cost. Yap, Abdul-Rahman, \& Wang (2016, p.2) synthesised design changes as "regular additions, omissions and adjustments to both design and construction of work in a building construction project that occurs after the award of a contract which affects the contract provisions and works conditions that make building construction dynamic and unstable". The alteration to original design will manifestly influence time and cost performance, suggesting the need for effective management of design changes.

Abdul-Rahman et al. (2015) conducted a synthesis of existing literature on delays and cost overruns in construction to determine the impacts of design changes to project performance. They reported that design changes have been identified as the most significant causing factor for overruns in both developed and developing countries around the world. They also accentuated that several studies were done in Malaysian context (e.g. Alaghbari et al., 2007; Memon et al., 2011; Sambasivan \& Yau, 2007) failed to recognise design changes as a major underlying cause of overruns. Nonetheless, frequent design changes are ranked fourth in the study by Memon, Abdul Rahman, \& Abdul Aziz (2012) on the cost overrun factors of large construction projects within the southern states of Peninsular Malaysia. This finding contradicts with other studies in similar fast-growing economies of Indonesia (see Kaming et al., 1997), Thailand (see Ogunlana, Promkuntong, \& Jearkjirm, 1996) and Taiwan (see Yang \& Wei, 2010) which ranked design changes as the major cause. For developed economy of the UK, design changes top the list of both time and cost overrun factors (Olawale \& Sun, 2010).

\section{DESIGN CHANGES INDUCED REWORK}

Several scholars have acknowledged the occurrences of rework due to design changes (e.g. Love, Mandal, \& Li, 1999; Palaneeswaran et al., 2014). A number of researchers have developed definitions for rework that can be found in construction management literature. According to Love et al. (1999), rework can be described as "the unnecessary effort of re-doing a process or activity that was incorrectly implemented at the first time". Ashford (1992, as cited in Love, 2002, p. 18) explains rework as "the process by which an item is made to conform to the original requirement by completion or correction". Fayek et al. (2003, p. 14) express rework as "activities in the field that have to be done more than once in the field, or activities which remove work previously installed as part of the project regardless of source, where no change order 
has been issued and no change of scope has been identified by the owner". Even though the definitions and interpretation of rework vary, one recurring theme prevails - rework refers to the need of redoing work consequent to nonconformance to requirements.

Rework cost typically ranges from $10 \%$ to $15 \%$ of the contract sum in a particular building construction project (Sun \& Meng, 2009). Love (2002) surveyed the rework costs from 161 Australian construction projects which revealed that rework increased a project's duration by $12.6 \%$ and added $20.7 \%$ to the project cost. From the case studies of four completed projects in California, Chang (2002) quantified schedule and cost growth of $69 \%$ and $25 \%$ respectively due to design changes. Post contract design changes can amount to almost $5 \%$ to $8 \%$ of the total project cost (Cox et al., 1999). Fundamentally, rework resulting in incremental cost due to the extra efforts of doing some work again and again within the construction project.

\section{METHODOLOGY FOR FRAMEWORK DEVELOPMENT}

"A conceptual framework in the sense being used here can be thought of as a diagram or map of a researcher's current view of the territory being investigated" (Miles \& Huberman, 1984, p. 33 as cited in Mitchell et al., 2011, p. 304). Figure 1 illustrates the methodology adopted in design and development of a conceptual framework which was adapted from Bhattacharya et al. (2013). This is appropriate for delimiting the scopes of the review which form the basis for the research design strategy and put forward the direction for fieldwork.

The first step of design was to identify the knowledge gaps within the research domain through critical appraisal of literature so that the themes and subthemes of the study could be formed. This phase is central for the establishment of the scope of the study. Subsequent, the conceptual framework was formulated basing on the evidence synthesised from the literature. The method employed for developing the conceptual framework was carried out in two stages. The initial stage was to develop a conceptual framework of causing factors influencing design changes while the succeeding stage is to expand the framework to include rework, decision-making and communication management parameters. The conceptual model was then verified internally by revisiting the parameters of the study and confirming whether the developed framework is representing the objectives of the study. 


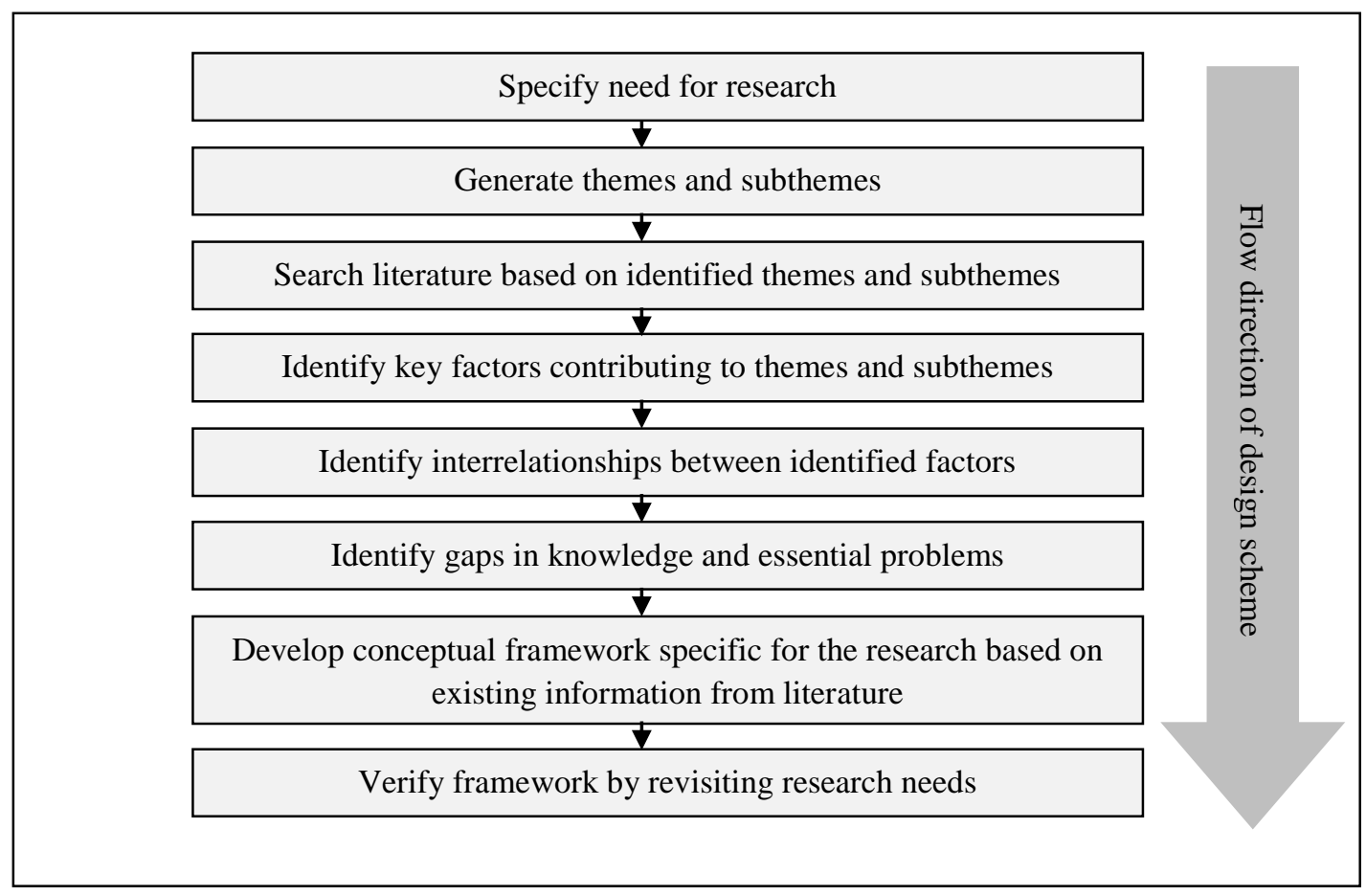

Figure 1: Flowchart showing steps for designing conceptual model (Source: Adapted from Bhattacharya et al., 2013, p. 336)

\section{CAUSES OF DESIGN CHANGES}

This section discusses the factors influencing design changes in building construction projects. To gain better insights on the design change dynamics, a strong understanding of causing factors is essential. Sun and Meng (2009) conducted a comprehensive review of the published literature that synthesising on the causes and effects of project change and presented noteworthy taxonomy to better explain changes in construction projects. Another study by Love et al. (2002) indicate that project changes may be stimulated by either inner and outer influences. Similarly, Alaghbari et al, (2007) highlight that the delay causes can be classified under internal and external causes respectively. Love et al. (2002) explain the cause-and-effect of changes as dynamics which can have a significant influence on project management systems. The dynamics can be classified into internal and external factors which are adapted in this paper. On the other hand, Mohamad et al. (2012) categorised the sources of design changes from clients, consultants and contractors who are the primary parties in building construction projects. In this paper, internal factors may be due to the client, the design, the site and/or the contractor induced causes. Figure 2 exhibits the conceptual framework for causing factors influencing design changes. 


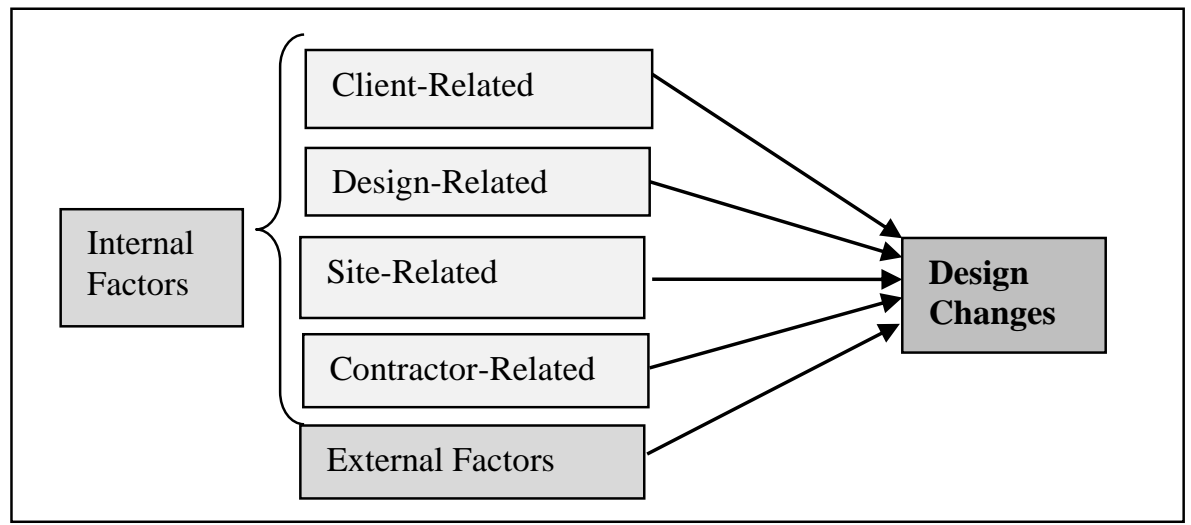

Figure 2: Conceptual framework of causing factors influencing design changes

\subsection{CLASSIFICATION OF CAUSES OF DESIGN CHANGES}

A plethora of studies has been done by scholars to examine the underlying basis and nature of changes in construction projects. However, the studies on causing factors of design changes are not that prevalent. The following section reviews the existing literature that focuses on the causes of design changes in construction projects. The literature is further synthesised to design cause-and-effect diagram for design changes that is depicted in Figure 3. Table 1 presents the summary of the sources from existing literature on the identified causing factors of design changes.

Table 1: A review of causing factors influencing design changes in construction

\begin{tabular}{ll}
\hline Causing factors & Authors \\
\hline A. Internal Factors & Al-Momani (2000); Alnuaimi et al. (2010); El-Razek et al. (1995); \\
\hline i. Client-related & Federal Construction Council (1983); Hwang et al. (2014); Ijaola \& \\
& Iyagba (2012); Josephson et al. (2002); Mohamad et al. (2012); \\
& Ogunlana et al. (1996); Thyssen et al. (2010); Wu et al. (2005) \\
\hline ii. Design-related & Alaghbari et al. (2007); Al-Momani (2000); Chang (2002); Cox et al. \\
& (1999); González \& González (2014); Hamzah et al. (2012); Han et \\
& al. (2012, 2013); Ijaola \& Iyagba (2012); Josephson et al. (2002); \\
& Kaming et al. (1997); Koskela et al. (2002); Love \& Edwards (2004); \\
& Mendelsohn (1997); Mohamad et al. (2012); Ogunlana et al. (1996); \\
& Sun \& Meng (2009); Wu et al. (2005) \\
\hline iii. Site-related & Frimpong et al. (2003); Hsieh et al. (2004); Love et al. (2002); \\
& Mohamad et al. (2012); Sambasivan \& Yau (2007) \\
\hline iv. Contractor-related & Alaghbari et al. (2007); González \& González (2014); Mohamad et \\
& al. (2012); Sun \& Meng (2009); Wu et al. (2005) \\
\hline B. External Factors & Aiyetan et al. (2011); Alaghbari et al. (2007); Chang et al. (2011); \\
& Chang (2002); Doloi et al. (2012); Hsieh et al. (2004); Love et al. \\
& (2002); Sambasivan \& Yau (2007); Sun \& Meng (2009); Wu et \\
& al.(2005) \\
\hline
\end{tabular}




\subsection{CLIENT-RELATED CAUSES}

Hwang et al. (2014) define "client-related rework as the rework that directly originated from client and client's representatives". The study reported that "replacement of materials by the client" was the most likely cause of change while client-related rework is mainly triggered by "change of plans or scope by the client”. Similarly, Josephson et al. (2002) note the contributing factors of the client to rework in Swedish construction industry are mainly client's changes, extra orders, bad choice of material/method and wrong information. According to a study by Mohamad et al. (2012), design changes are greatly initiated by the clients. They listed three major causes of design changes attributed to the clients were "modifications to the original design", "addition of new work/scope" and "unclear initial design brief". Some other significant causes comprise of "desire to use better specification", "desire to use alternative material/new technology" and "omission of works/scopes". Similarly, a technical report by Federal Construction Council (1983) highlights that unwarranted changes in construction are due to client or client's representatives. This is further supported by Alnuaimi et al. (2010) in a study on Oman's government projects where client's additional works are identified as the topmost factor causing change orders. Again, Ijaola and Iyagba (2012) also reported identical findings in both Nigeria and Oman. Another study by Al-Momani (2000) reported that delays in public construction projects in Jordan are related to user changes. El-Razek et al. (1995) also have almost similar findings in Egypt, Ogunlana et al. (1996) in Thailand and Wu et al. (2005) in Taiwan. According to Hwang, Zhao and Goh (2014), client-related factors are "change of plans or scope by the client", "inadequate/ uncomprehensive project objectives by the client", "change in specification by the client", "financial problems faced by client", "impediment in prompting the decision making by the client", "replacement of materials by the client", "change in specification by the client", and "obstinate nature of the client". The data was collected from 381 construction projects undertaken by 51 construction organisations in Singapore. Numerous studies show that client-related changes contributed weighty effects on the project schedule and cost outcomes. Therefore, client values are important and should be fully understood at the early phase of the project (Thyssen et al., 2010).

\subsection{DESIGN-RELATED CAUSES}

According to Mendelsohn (1997), almost $75 \%$ of problems or rework on construction project were induced at the design phase. The lack of communication between design consultants can lead to mistakes and oversights in project documentation (Love et al., 2004). The design and delivery team often misinterpret the client's requirements in the project (Koskela et al., 2002; Thomson et al., 2003). Therefore, Love et al. (2004) suggest the communication and harmonious relationship between clients and their design team and the involvement of clients in the design process can appreciably cut design-related rework. Key designerrelated factors include the irregular progression of the project was not prophesied at the design stage, errors in designing as well as using obsolete design and construction benchmarks and adoption of inept construction technology (Al-Momani, 2000). Modification to design was indicated as the second most common problem resulting in change order in both Oman and Nigeria (Ijaola \& Iyagba, 2012). According 
to Sun and Meng (2009), design consultants engendered changes include "poor/incomplete drawings", “design changes due to poor brief", "errors and omissions" and "inconsistent site condition". Mohamad et al. (2012) reported "improper design/ part of design improvement", "inconsistent information in drawings", "the discrepancy between contracts", "lack of geotechnical investigation/ wrong interpretation of findings and insufficient detail of existing site condition" as the factors that caused design changes in residential reinforced concrete buildings. Another study by Cox et al. (1999) looks into design deviations after the award of the contract for construction. Frequent reasons cited comprising of “designer's omission in tender documents", "coordination defects in tender documents", "the employer has changed his requirements", and "new information on site conditions". Josephson et al. (2002) note the contributing factors of design to rework in Swedish construction industry are "a lack of co-ordination, unsuitable design", "faulty design and incomplete drawings". Kaming et al. (1997) describe the magnitude of design changes depend on upon the extensiveness of site investigation, the entirety and availability of working drawings at the proposal stage and unanticipated circumstances during the implementation stage. Consultant's inability (Hsieh et al., 2004), design omissions (Alaghbari et al., 2007), incomplete drawings (Ogunlana et al., 1996), design errors (Hamzah et al., 2012) and poor quality of design (Wu et al., 2005) caused cost and schedule increases. Design changes constitute to failure in the coordination of design information (Mokhtar et al., 1998). The defective design is commonly caused by human errors (Andi \& Minato, 2003). Design errors can significantly degrade project performance by generating rework, requiring additional time and resource expenditure (Han et al., 2013).

\subsection{SITE-RELATED CAUSES}

Project specific dynamics include location conditions (Love et al., 2002) and underground conditions (Hsieh, Lu, \& Wu, 2004; Mohamad et al., 2012; Sambasivan \& Yau, 2007). The inherent site conditions of a project will affect the project performance (Frimpong et al., 2003).

\subsection{CONTRACTOR-RELATED CAUSES}

According to Mohamad et al. (2012), design changes induce by the contractor are "due to contractor's request to use the available material", "to use alternative construction method to save time", "to use alternative construction methods to save money", "to rectify construction mistakes", and "to improve the quality of works at site". Similarly, modification of construction methods to suit current site conditions, contractor request for original construction methods to be replaced by a new method as well as improper construction or human errors leading to on-site repair work are listed by Wu et al. (2005). Poor planning of project caused errors in execution of tasks and inappropriate construction methods (González \& González, 2014; Alaghbari et al., 2007). On the other hand, Sun and Meng (2009) included "poor site/project management skills", "delays in appointing subcontractor", "delay of subcontractors" work", "poor workmanship", "low productivity", and "poor logistic control" as the relevant factors.

\subsection{EXTERNAL-RELATED CAUSES}


Project outcome is most impacted by the regulation imposed by the government (Love et al., 2002). "Change of work rules/regulation by the government agencies", "neighbourhood communities" and "coordinating with utility systems" as some of the external factors described in Hsieh et al. (2004)'s study. In a separate study, Sun and Meng (2009), Chang et al. (2011), Wu et al. (2005) and Chang (2002) also recognised change orders owing to legislative or policy changes as a critical external factor. In Malaysia, the external causes are regulatory changes and the problem with neighbours (Sambasivan \& Yau, 2007). Alaghbari et al. (2007) further expanded the external factors to include "materials on the market", "equipment and tools on the market", "economic conditions"," law and regulation", and "external works due to public agencies (roads, utilities and public services)". Aiyetan, Smallwood and Shakantu (2011) point out "physical environmental conditions", "economic policy" and "socio-political conditions" as factors in their study. Doloi et al. (2012) even argue that lack of communication with local authorities will influence project performance.

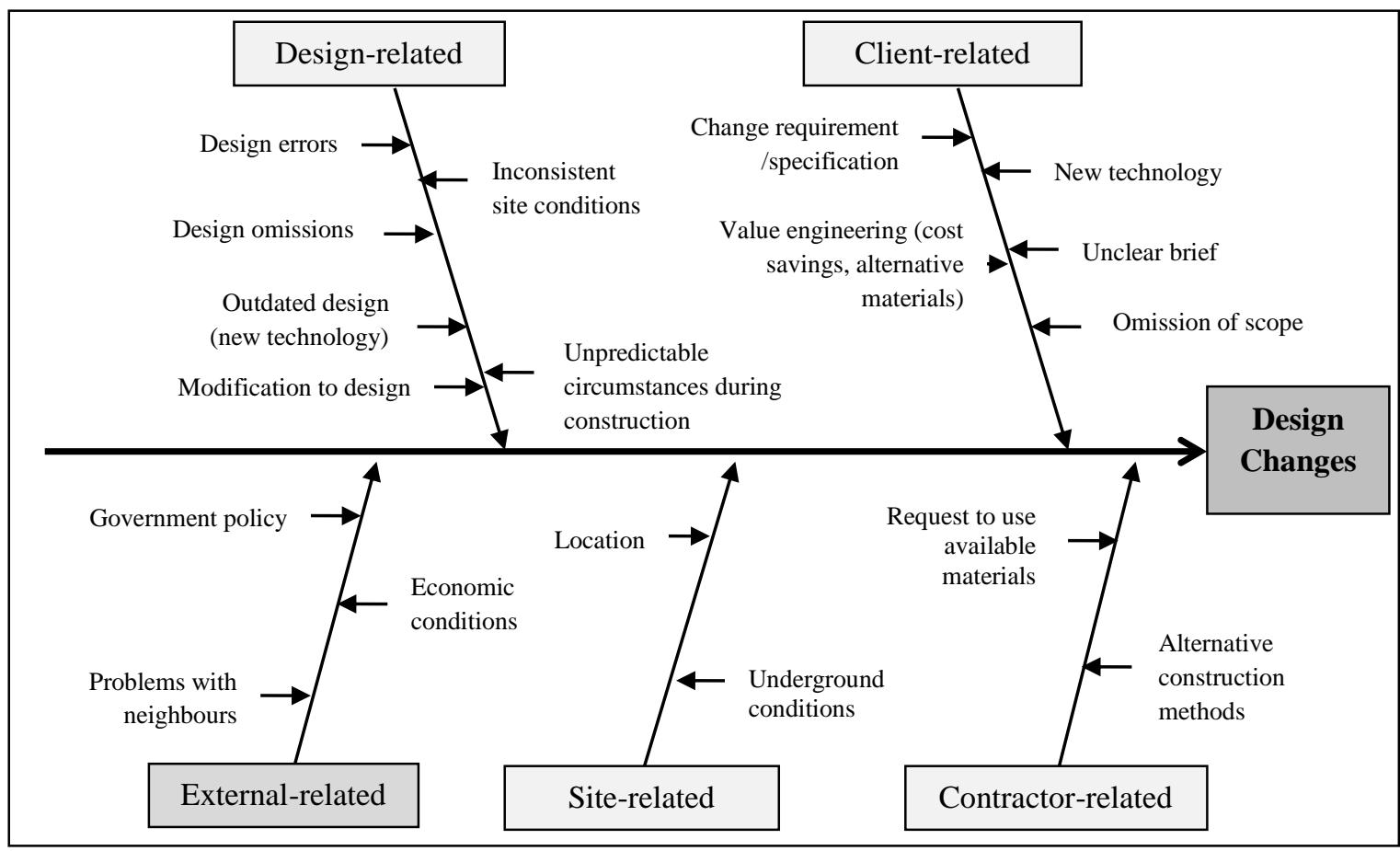

Figure 3: Generic cause-and-effect diagram of design changes

\subsection{INDIRECT EFFECTS OF DESIGN CHANGES AND REWORK}

As previously noted, design changes in building construction projects will inevitably degrade project performance due to the consequences of rework. Rework is wastefully owing to its non-value adding activities that take up time and require more resources or require storage but does not add value to output. Consequently, rework affects the productivity and performance of work progress. A considerable amount of studies has indicated the indirect effects of rework are a notable delay and disruption as well as unnecessary claim and dispute (Table 2). 
Table 2: A review of effects of rework to project performance

\begin{tabular}{ll}
\hline Effects of rework & Authors \\
\hline Delay and disruption & Arashpour et al., 2014; Hegazy, Said, \& Kassab, 2011; Howick et al., \\
& 2009; Ibbs, 2013; Williams, Ackermann, \& Eden, 2003 \\
\hline Claim and dispute & Alnuaimi et al., 2010; Cruz, 2014; Ibbs, 2012; Love, Smith, \& Li, \\
& 1999; Love, Edwards, \& Smith, 2015 \\
\hline
\end{tabular}

Design changes are paramount to delay, disruption, excessive claims and disputes. According to Sun and Meng (2009), the indirect effects of project changes will have damaging effects on project performance. Delay in building construction projects often due to loss of productivity, loss of rhythm, coordination issues, the morale of workforce, and so on (Hanna et al. 1999). Rework causes interruptions to overall workflow. Disruption is fundamental to reduced productivity and increased rework on the project (Lover \& Li, 2000). More recently, a study by Arashpour et al. (2014) stress on improving project delivery by effectively managing rework and its related variables.

Lost productivity will trigger strenuous relationship among the contracting parties. Difficulty in quantifying disruption effects leads to adversarial tension (Lee et al, 2006). Hence, disputes and claims over project changes can be minimised when the problems are recognised at the earlier stages of the project, especially at the point of decision-making.

\subsection{COMMUNICATION MANAGEMENT IN BUILDING PROJECTS}

According to Naoum (1994), the most common triggers of project changes are a lack of timely and effective communication and poor synergy. These variables are consistent with other scholars reporting on the causes of overruns in many parts of the world. As building construction is performed under the fragmented projectbased environment (Alashwal \& Fong, 2015), communication planning becomes complex but essential (Laufer, Shapira, \& Telem, 2008). In fact, Project Management Institute (2013) acknowledges communication management as an imperative domain within Project Management Body of Knowledge (PMBOK).

Senaratne and Ruwanpura (2016) carried out three case studies to study the project communication process within construction projects in India. They reported that effective communication process brings team members together, stimulating a collaborative working environment that hinders adversarial effects of "them and us" attitude. In a separate study, Anantatmula (2015) embarked on establishing contributing factors to improve project performance with designed communication as the principal variable that influences policies and procedures, collaborative culture, and cohesive project team in the project performance enhancement model. From the in-depth interviews with 56 respondents, $72 \%$ of the participants were in the opinion that cohesive project team leads to participation in decision making. These two notable findings are akin to the claim by Dainty, Moore, \& Murray (2006) indicating communication 
as a route to trust and collaborative working. Also, they assert the use of communication as a route to individual and organisational learning.

\section{FINDINGS AND FORMULATION OF FRAMEWORK}

A framework for management of design changes in building construction projects by placing emphasis on management decision is proposed (Figure 4). The literature suggests that effective communication leads to team collaboration that encourages project learning which ultimately improves expert judgement in decision-making. With this concept in mind, effective communication is introduced as a moderating variable to the conceptual framework in facilitating design change management.

Informed decision-making capability is facilitated by effective communication process which tends to improve expert judgement of project team members. Greater information exchange and sharing of experiences are enthused within a cohesive team and collaborative working culture made possible through project communication management. As a result, preventable design changes would be mitigated whereas the inevitable design changes can be proficiently managed. Also, the impacts can be envisaged at the early stage or at the point of design change request in order to minimise the risk of the project to potential claims and disputes at the tail end of the project.

Design changes induced rework will have a significant influence on the soft factors such as motivation of workers and level of work productivity. These soft factors are critical to project time and cost outcomes. Undesirable outcomes will eventually lead to excessive claims and disputes at the later part of the project. This framework provides a holistic view of the cause-and-effect (causal relationship) of design changes to project time and cost performance. As emphasised by Ahiaga-Dagbui et al. (2015), the fundamental ability in understanding time and cost overruns is not the ability to itemise or sort causing factors but rather the aptitude to comprehend associations and the dynamics between the different sources. This framework, therefore, addresses the methodological deficiency and in line with the paradigm shift propagated by Ahiaga-Dagbui et al. (2015). Henceforth, the framework extends a basis for the development of system dynamics or causal loop mapping to investigating the problem of design changes in building construction projects. 


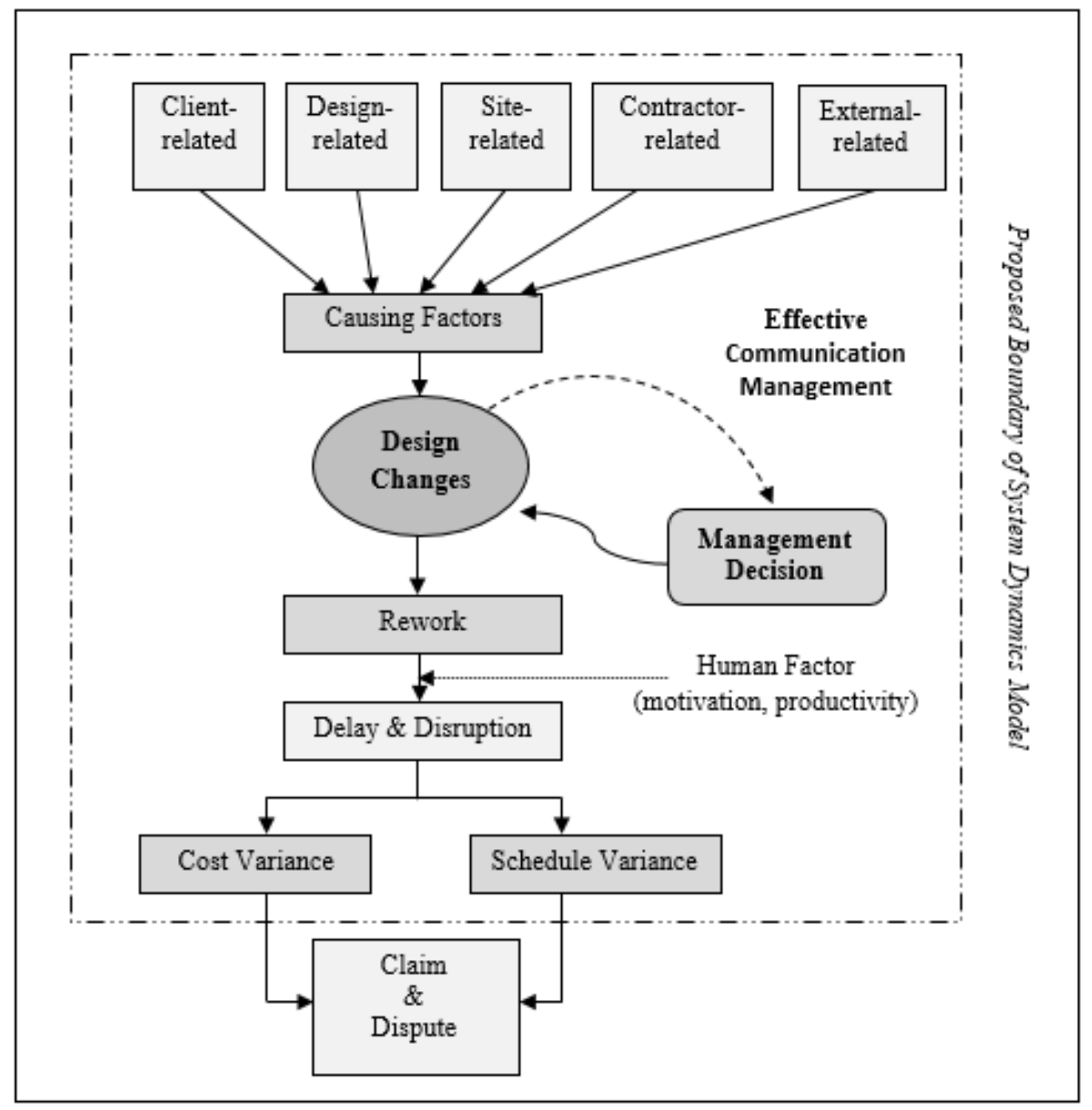

Figure 4: The conceptual framework of design change management

\section{PROPOSED APPROACH FOR DESIGN CHANGE MANAGEMENT}

Alsehaimi, Koskela, and Tzortzopoulos (2013) stress the need for alternative research approaches in construction project management research. This claim is further justified by Ahiaga-Dagbui et al. (2015) that identified a methodological gap in current research that lack system thinking and demonstrable causality. By employing system thinking to the problem of design changes to understand the factors influencing the occurrence of design changes at various times in the project, system thinking can lead the construction industry towards realising how to prevent or mitigate delay and disruption impacts by anticipating when and where design changes are most likely to occur.

System dynamics (SD) is a methodology for analysing complex systems and problems with the aid of computer simulation software. It is an experimental approach to system thinking (Sterman, 2000). SD modelling has brought a new view to project management, enabling understanding of the behaviour of complex projects that was not accessible with other methods (Howick et al., 2009). SD is about studying 
complex and dynamic systems which change over time, and about finding the "why" (causes) and "how" (pattern) of system changes. According to (Sterman, 2000), SD models are suitable for complex and highly dynamic systems which involve multiple feedback processes with non-linear relationships as well as encompass both "hard" and "soft" data. Human factors such as motivation and productivity are considered as soft variables.

SD models are providing a systematic analysis of the strategic issues of project management (Rodrigues \& Bowers, 1996). SD models have been successfully applied to construction project management (Chang, Ogunlana, \& Saeed, 1991); effect of rework on project performance (Love et al., 2002); change management in construction (Lee, Peña-Mora, \& Park, 2006); decision making in construction (Bank et al., 2010); delay and disruptions in construction (Howick et al., 2009); procurement strategies (Park et al., 2009); outsourcing construction services (Lisse, 2013) and analyzing project cost overruns (Eden, Williams, \& Ackermann, 2005), among others. Above all, SD models can complement the shortcomings of traditional tools and techniques (Ahiaga-Dagbui et al., 2015; Rodrigues, 1994).

To facilitate learning and communication process, Lyneis and Ford (2007) advocate the application of SD to be expanded into 'management simulator' (Sterman, 2000) or simply management training tool for visualising and understanding of how the design change influence project performance. The flow diagrams in SD are a vivid tool for this purpose (Otto, 2008). This proactive approach allows practitioners to review and challenge assumptions and plans before problems arise, which increase the probability of project success.

\section{CONCLUSION}

Research into determining the causes of time delays and cost overruns has reached saturation point; consistently the same causal variables are identified. Yet, construction projects suffering from overruns are still on the rise. It is worth mentioning that for most studies conducted in the Malaysian context, design changes failed to be recognised as a significant contributing factor for degrading project performance. As a result, little is known about the causing factors of design changes in the fast-growing economy such as Malaysia where poor project delivery outcomes are to a large extent arising due to problems associated with design changes. The adversarial effects of design changes are rework which leads to delay and disruption over and above claim and disputes. In turn, this paper rectifies the situation with a comprehensive literature review to formulate a conceptual design change management framework. It is suggested that effective communication leads to collaboration and the cohesive team which encourages dynamic involvement in management decision-making. The framework which is a noteworthy outcome from this study stresses the importance of effective communication process and informed management decision as the control mechanism in mitigating design changes and rework in building construction projects.

While empirical evidence for this framework is still in an emerging state, it provides some notable insights to researchers and practitioners in construction management field on the understanding of the causing factors of design changes and its detrimental impacts to project schedule and cost outcomes in a holistic 
manner. As part of the research agenda, it is interesting to investigate in depth the influence of effective communication process on project learning in enhancing expert judgement in design changes mitigation efforts. It is also crucial to explore the enablers for project learning in construction project environment.

There has always been a limitation with a static model for the understanding of dynamic and non-linear problems. It is important to reiterate that there is a lack of systems approach in overruns studies. Static thinking presents interrelationships in linear cause-and-effect chains while system thinking elucidates them in circular cause-and-effect chains. Overruns causation can only be apprehended by considering the overall system, determine where they occur and distinguish how several variables dynamically interact with one another. For future studies, this paper suggests expanding the proposed conceptual framework into causal loop diagram (CLD) with systems dynamics approach to bridge the methodological deficiencies. The CLD clearly illustrates the dynamics of design changes within the project lifecycle and how the impacts will affect project performance (time and cost).

\section{REFERENCES}

Abdul-Rahman, H., Wang, C., \& Yap, J. B. H. (2015). Impacts of design changes on construction project performance: Insights from a literature review. In 14th Management In Construction Researchers' Association (MiCRA 2015) Annual Conference and General Meeting. Kuala Lumpur, Malaysia.

Ahiaga-Dagbui, D. D., Smith, S. D., Love, P. E. D., \& Ackermann, F. (2015). Spotlight on construction cost overrun research: superficial, replicative and stagnated. In A. Raiden \& E. Aboagye-Nimo (Eds.), 31st Annual ARCOM Conference. Lincoln, UK: Association of Researchers in Construction Management.

Aiyetan, A., Smallwood, J., \& Shakantu, W. (2011). A systems thinking approach to eliminate delays on building construction projects in South Africa. Acta Structilia, 19-39.

Akinsola, A. O., Potts, K. F., Ndekugri, I., \& Harris, F. C. (1997). Identification and evaluation of factors influencing variations on building projects. International Journal of Project Management, 15(4), 263-267.

Alaghbari, W., Kadir, M. R. A., Salim, A., \& Ernawati. (2007). The significant factors causing delay of building construction projects in Malaysia. Engineering, Construction and Architectural Management, 14(2), 192-206.

Alashwal, A. M., \& Fong, P. S.-W. (2015). Empirical study to determine fragmentation of construction projects. Journal of Construction Engineering and Management, 141(7), 4015016.

Al-Momani, A. H. (2000). Construction delay: a quantitative analysis. International Journal of Project Management, 18(1), 51-59. 
Alnuaimi, A. S., Taha, R. A., Al Mohsin, M., \& Al-Harthi, A. S. (2010). Causes, effects, benefits, and remedies of change orders on public construction projects in Oman. Journal of Construction Engineering and Management, 136(5), 615-622.

Alsehaimi, A., Koskela, L., \& Tzortzopoulos, P. (2013). Need for alternative research approaches in construction management : Case of delay studies. Journal of Management, (October), 407-414.

Anantatmula, V. S. (2015). Strategies for enhancing project performance. Journal of Management in Engineering, 31(6), 4015013.

Andi, \& Minato, T. (2003). Representing causal mechanism of defective designs: A system approach considering human errors. Construction Management and Economics, 21(3), 297-305.

Arashpour, M., Wakefield, R., Blismas, N., \& Lee, E. W. M. (2014). Analysis of disruptions caused by construction field rework on productivity in residential projects. Journal of Construction Engineering and Management, 140(2), 4013053.

Assaf, S. A., \& Al-Hejji, S. (2006). Causes of delay in large construction projects. International Journal of Project Management, 24(4), 349-357.

Bank, L. C., McCarthy, M., Thompson, B. P., \& Menassa, C. C. (2010). Integrating BIM with system dynamics as a decision-making framework for sustainable building design and operation. In Proceedings of the First International Conference on Sustainable Urbanization (ICSU 2010) (pp. 15-17). Hong Kong, China.

Bhattacharya, N., Lamond, J., Proverbs, D., \& Hammond, F. (2013). Development of conceptual framework for understanding vulnerability of commercial property values towards flooding. International Journal of Disaster Resilience in the Built Environment, 4(3), 334-351.

Burati, J. L., Farrington, J. J., \& Ledbetter, W. B. (1992). Causes of Quality Deviations in Design and Construction. Journal of Construction Engineering and Management.

Chang, A. S. T. (2002). Reasons for cost and schedule increase for engineering design projects. Journal of Management in Engineering, 18(1), 29-36.

Chang, A. S. T., Shih, J. S., \& Choo, Y. S. (2011). Reasons and costs for design change during production. Journal of Engineering Design, 22(4), 275-289.

Chang, C. L., Ogunlana, S., \& Saeed, K. (1991). Construction Project Management: A System Dynamics Approach. In Proceedings of the 1991 System Dynamics Conference (p. 108). Bangkok, Thailand: International System Dynamics Society.

Charles, S. P. R., Wanigarathna, N., \& Sherratt, F. (2015). Construction project change : Investigating cost and benefits. In 31st Annual ARCOM Conference (pp. 833-842). Lincoln, UK: Association of 
Researchers in Construction Management.

Construction Industry Development Board (CIDB). (2016). Construction statistics quarterly bulletin.

Cox, I. D., Morris, J. P., Rogerson, J. H., \& Jared, G. E. (1999). A quantitative study of post contract award design changes in construction. Construction Management and Economics, 17(4), 427-439.

Cruz, N. E. R. (2014). Application of system dynamics to model rework in construction projects.

Dainty, A., Moore, D., \& Murray, M. (2006). Communication in construction: theory and practice. London: Taylor \& Francis.

Doloi, H., Sawhney, A., Iyer, K. C., \& Rentala, S. (2012). Analysing factors affecting delays in Indian construction projects. International Journal of Project Management, 30(4), 479-489.

Eden, C., Williams, T., \& Ackermann, F. (2005). Analysing project cost overruns: Comparing the "measured mile"; analysis and system dynamics modelling. International Journal of Project Management, 23(2), 135-139.

El-Razek, M. E. A., Bassioni, H. A., \& Mobarak, A. M. (1995). Causes of delay in large building construction projects in Egypt. Journal of Management in Engineering, 11(2), 45-50.

Fayek, A. R., Dissanayake, M., \& Campero, O. (2003). Measuring and classifying construction field rework: A pilot study.

Federal Construction Council. (1983). Managing Changes in the Construction Process. Washington DC: Consulting Committee on Contract Management, Technical Report, National Academy Press.

Frimpong, Y., Oluwoye, J., \& Crawford, L. (2003). Causes of delay and cost overruns in construction of groundwater projects in a developing countries; Ghana as a case study. International Journal of Project Management, 21(5), 321-326.

González, P., \& González, V. (2014). Analysis of causes of delay and time performance in construction projects. Journal of Construction Engineering and Management, 140(1), 1-9.

Hamzah, N., Khoiry, M. A., Arshad, I., Badaruzzaman, W. H. W., \& Tawil, N. M. (2012). Identification of the causes of construction delay in Malaysia. World Academy of Science, Engineering and Technology, 72(12), 312-317.

Han, S., Lee, S., \& Peña-Mora, F. (2012). Identification and quantification of non-value-adding effort from errors and changes in design and construction projects. Journal of Construction Engineering and Management, 138(1), 98-109.

Han, S., Love, P., \& Peña-Mora, F. (2013). A system dynamics model for assessing the impacts of design errors in construction projects. Mathematical and Computer Modelling, 57(9-10), 2044-2053. 
Hanna, A. S., Russell, J. S., Nordheim, E. V, \& Bruggink, M. J. (1999). Impact of change orders on labor efficiency for electrical construction. Journal of Construction Engineering and Management, (July/August), 224-232.

Hegazy, T., Said, M., \& Kassab, M. (2011). Incorporating rework into construction schedule analysis. Automation in Construction, 20(8), 1051-1059. http://doi.org/10.1016/j.autcon.2011.04.006

Howick, S. M., Ackermann, F., Eden, C., \& Williams, T. M. (2009). System dynamics and disruption and delay in complex projects. In Encyclopaedia of compexity and system science. Springer.

Hsieh, T. Y., Lu, S. T., \& Wu, C. H. (2004). Statistical analysis of causes for change orders in metropolitan public works. International Journal of Project Management, 22(8), 679-686.

Hwang, B. G., Zhao, X., \& Goh, K. J. (2014). Investigating the client-related rework in building projects: The case of Singapore. International Journal of Project Management, 32(4), 698-708.

Ibbs, W. (2012). Construction change : Likelihood, severity, and impact on productivity. Journal of Legal Affairs and Dispute Resolution in Engineering and Construction, (August), 67-73.

Ibbs, W. (2013). Thinking about delay, disruption, and the cumulative impact of multiple changes. Journal of Legal Affairs and Dispute Resolution in Engineering and Construction, 5(3), 109-112.

Ijaola, I. a., \& Iyagba, R. O. (2012). A comparative study of causes of change orders in public construction project in Nigeria and Oman. Journal of Emerging Trends in Economics and Management Sciences, $3(5), 495-501$.

Isa, Kalsum, N. M., Samad, Z. A., \& Alias, A. (2014). A review on sustainability principles of building: Formulation of a theoretical framework. Journal of Surveying, Construction and Property (JSCP), $5(1), 1-16$.

Josephson, P.-E., Larsson, B., \& Li, H. (2002). Illustrative Benchmarking Rework and Rework Costs in Swedish Construction Industry. Journal of Management in Engineering, 18(2), 76-83.

Kaming, P. F., Olomolaiye, P. O., Holt, G. D., \& Harris, F. C. (1997). Factors influencing construction time and cost overruns on high-rise projects in Indonesia. Construction Management and Economics, 15(1), 83-94.

Koskela, L., Huovila, P., \& Leinonen, J. (2002). Design management in building construction: from theory to practice. Journal of Construction Research, 3(1), 1.

Laufer, A., Shapira, A., \& Telem, D. (2008). Communicating in dynamic conditions: how do on-site construction project managers do it? Journal of Management in Engineering, 24(2), 75-86.

Lee, H., Ryu, H., Yu, J., \& Kim, J. (2006). Method for calculating schedule delay considering lost productivity. Journal of Construction Engineering and Management, 131(11), 1147-1154. 
http://doi.org/10.1061/(ASCE)0733-9364(2005)131:11(1147)

Lee, S., Peña-Mora, F., \& Park, M. (2006). Web-enabled system dynamics model for error and change management on concurrent design and construction projects. Journal of Computing in Civil Engineering, 20(4), 290-300.

Lisse, S. (2013). System Dynamics for Outsourcing Construction Services. International Journal of Construction Engineering and Management, 2(3), 53-61.

Love, P. E. D. (2002). Influence of project type and procurement method on rework costs in building construction projects. Journal of Construction Engineering and Management, 128(1), 18-29.

Love, P. E. D., \& Edwards, D. J. (2004). Determinants of rework in building construction projects. Engineering, Construction and Architectural Management, 11(4), 259-274.

Love, P. E. D., \& Edwards, D. J. (2004). Forensic project management: The underlying causes of rework in construction projects. Civil Engineering and Environmental Systems, 21(3), 207-228.

Love, P. E. D., Edwards, D. J., \& Smith, J. (2015). Rework causation : Emergent theoretical insights and implications for research. Journal of Construction Engineering \& Management, (January 2016), 19.

Love, P. E. D., Frani, Z., \& Edwards, D. J. (2004). A rework reduction model for construction projects. IEEE Transactions on Engineering Management, 51(4), 426-440.

Love, P. E. D., Holt, G. D., Shen, L. Y., Li, H., \& Irani, Z. (2002). Using systems dynamics to better understand change and rework in construction project management systems. International Journal of Project Management, 20(6), 425-436.

Love, P. E. D., Mandal, P., \& Li, H. (1999). Determining the causal structure of rework influences in construction. Construction Management and Economics, 17, 505-517.

Love, P. E. D., \& Sing, C.-P. (2013). Determining the probability distribution of rework costs in construction and engineering projects. Structure and Infrastructure Engineering, 9(11), 1136-1148.

Love, P. E. D., Smith, J., \& Li, H. (1999). The propagation of rework benchmark metrics for construction. International Journal of Quality \& Reliability Management, 16(7), 638-658.

Lover, P. E. D., \& Li, H. (2000). Quantifying the causes and costs of rework in construction. Construction Management and Economics, 28, 479-490.

Lyneis, J. M., \& Ford, D. N. (2007). System dynamics applied to project management: a survey, assessment, and directions for future research. System Dynamics Review, 23(2-3), 157-189.

Memon, A. H., Abdul Rahman, I., \& Abdul Aziz, A. A. (2012). The cause factors of large project's cost 
overrun: a survey in the southern part of Peninsular Malaysia. International Journal of Real Estate Studies (INTREST), 7(2), 1-15.

Memon, A. H., Abdul Rahman, I., Razaki Abdullah, M., \& Abdul Aziz, A. A. (2011). Time overrun in construction projects from the perspective of project management consultant (PMC). Journal of Surveying, Construction \& Property, 2(1), 54-66.

Mendelsohn, R. (1997). The constructibility review process: A constructor's perspective. Journal of Management in Engineering, 13(3), 17-19.

Mitchell, A., Frame, I., Coday, A., \& Hoxley, M. (2011). A conceptual framework of the interface between the design and construction processes. Engineering, Construction and Architectural Management, $18(3), 297-311$.

Mohamad, M., Nekooie, M., \& Al-Harthy, A. (2012). Design changes in residential reinforced concrete buildings: The causes, sources, impacts and preventive measures. Journal of Construction in Developing Countries, 17(2), 23-44.

Mokhtar, A., Bédard, C., \& Fazio, P. (1998). Information model for managing design changes in a collaborative environment. Journal of Computing in Civil Engineering, 12(2), 82-92.

Naoum, S. G. (1994). Critical analysis of time and cost of management and traditional contracts. Journal of Construction Engineering and Management, 120(4), 687-705.

Ng, E. (2015, May 19). No cost overrun for klia2, says Liow | The Edge Markets. The Edge Markets. Retrieved from http://www.theedgemarkets.com/my/article/no-cost-overrun-klia2-says-liow

Ogunlana, S. O., Promkuntong, K., \& Jearkjirm, V. (1996). Construction delays in a fast-growing economy: Comparing Thailand with other economies. International Journal of Project Management, 14(1), 3745.

Olawale, Y. A., \& Sun, M. (2010). Cost and time control of construction projects: Inhibiting factors and mitigating measures in practice. Construction Management and Economics, 28(5), 509-526.

Onwuegbuzie, A. J., Leech, N. L., \& Collins, K. M. T. (2012). Qualitative analysis techniques for the review of the literature. The Qualitative Report, 17(56), 1-28. Retrieved from http://www.nova.edu/ssss/QR/QR17/onwuegbuzie.pdf

Otto, P. (2008). A system dynamics model as a decision aid in evaluating and communicating complex market entry strategies. Journal of Business Research, 61(11), 1173-1181.

Palaneeswaran, E., Love, P. E. D., Kumaraswamy, M. M., \& Ng, T. S. T. (2014). Causal ascription of rework in building and civil engineering projects: A multivariate exploration. Engineering, Construction and Architectural Management, 21(1), 111-126. 
Park, M., Ji, S., Lee, H., \& Kim, W. (2009). Strategies for design-build in Korea using system dynamics modeling. Journal of Construction Engineering and Management, 135(11), 1125-1138.

Park, M., \& Peña-Mora, F. (2003). Dynamic change management for construction: Introducing the change cycle into model-based project management. System Dynamics Review, 19(3), 213-242.

Project Management Institute. (2013). A guide to the project management body of knowledge (PMBOK Guide) (5th ed.). Pennsylvania,USA: Project Management Institute, Inc.

Rodrigues, A. (1994). The role of system dynamics in project management: a comparative analysis with traditional models. In 1994 International System Dynamics Conference (pp. 214-225). Sterling, Scotland.

Rodrigues, A., \& Bowers, J. (1996). The role of system dynamics in project management. International Journal of Project Management, 14(4), 213-220.

Sambasivan, M., \& Yau, S. W. (2007). Causes and effects of delays in Malaysian construction industry. International Journal of Project Management, 25(5), 517-526.

Senaratne, S., \& Ruwanpura, M. (2016). Communication in construction: A management perspective through case studies in Sri Lanka. Architectural Engineering and Design Management, 12(1), 3-18.

Shehu, Z., Endut, I. R., Akintoye, A., \& Holt, G. D. (2014). Cost overrun in the Malaysian construction industry projects: A deeper insight. International Journal of Project Management, 32(8), 1471-1480.

Sterman, J. D. (2000). Business dynamics: Systems thinking and modeling for a complex world. Boston: Irwin/McGraw-Hill.

Sun, M., \& Meng, X. (2009). Taxonomy for change causes and effects in construction projects. International Journal of Project Management, 27(6), 560-572.

Thomson, D. S., Austin, S. a., Devine-Wright, H., \& Mills, G. R. (2003). Managing value and quality in design. Building Research \& Information, 31(5), 334-345.

Thyssen, M. H., Emmitt, S., Bonke, S., \& Kirk-Christoffersen, A. (2010). Facilitating client value creation in the conceptual design phase of construction projects: A workshop approach. Architectural Engineering and Design Management, 6(1), 18-30.

Williams, T., Ackermann, F., \& Eden, C. (2003). Structuring a delay and disruption claim: An application of cause-mapping and system dynamics. European Journal of Operational Research, 148(1), 192 204.

Williams, T., Eden, C., Ackermann, F., \& Tait, A. (1995). The effects of design changes and delays of project costs. Journal of the Operational Research Society, 46(7), 809-818. 
Wu, C. H., Hsieh, T. Y., \& Cheng, W. L. (2005). Statistical analysis of causes for design change in highway construction on Taiwan. International Journal of Project Management, 23(7), 554-563.

Yang, J.-B., \& Wei, P.-R. (2010). Causes of Delay in the Planning and Design Phases for Construction Projects. Journal of Architectural Engineering, 16(2), 80-83.

Yap, J. B. H., Abdul-Rahman, H., \& Wang, C. (2016). A conceptual framework for managing design changes in building construction. MATEC Web of Conferences, 66, 21. 